\title{
Ways of Escape
}

Kathryn McKay and Christopher Boyle, University of New England, Australia

Harry picked it up and stared at it, his heart twanging like a giant elastic band. No one, ever, in his whole life, had written to him. Who would? He had no friends, no other relatives - he didn't belong to the library, so he'd never even got rude notes asking for books back. Yet here it was, a letter, addressed so plainly there could be no mistake:

\author{
Mr. H. Potter \\ The Cupboard under the Stairs \\ 4 Privet Drive \\ Little Whinging \\ Surrey"
}

Childhood has long been romanticised in both real life and within popular culture, yet the veneer of such romanticisation can be easily scratched. Myriad fictional worlds are grounded in stories of orphans and abandoned children, unloved and disconnected, scrabbling for survival, let alone love and acceptance. Before Harry Potter started his adventures at Hogwarts School of Witchcraft and Wizardry, he was an orphaned boy so unloved by his remaining family that the first letter he ever received was from a place he had never dreamt existed. Paddington Bear - who may have been a bear but was as childlike as any human character - arrived in London with a label around his neck asking someone to 'Please take care of this bear', trusting that someone would find him a good home. These are stories of love and adventure, hope and growing up, but these successes are also bound to their beginnings: the child who succeeds and thrives despite their poor beginning. These are the grand coming-of-age tales which comfort their reader - who may well also be a lonely, unloved, and disconnected child - that one day, everything will be better. These tales give children hope

In real life though, how does society treat children who arrive in a foreign land with, if not a literal label around their necks asking for help, a metaphoric one? How do we protect the rights (and lives) of children when they are so often voiceless and dependent upon adults for survival? How do we ensure that all children - even the most disconnected - can still hope that, one day, everything will be better?

Recently, it seems that polarized debates around simple survival (where hope may be scarce) and a high quality of life (where hope flourishes) are (often) bound to two types of children - the children who belong to our community (where we debate the best potential options), and children who belong to other communities (where we problematise their survival). So we have two categories of child here. We have 'ours' and 'the others'. We would not allow ours to be treated as many of the others are without raising a united voice in protest. Do we protest loudly enough for the rights the others? Are we united for them? Further, our arguments about these children are strongly linked to our perceptions around the types of adults we believe these children will become. Children of ours will grow into adults like us who we perceive will 
value-add to their community; the children of the others are perceived more likely to grow into the adults we distrust most - those who would only take from what our children have added to the community.

In children's fiction though, we are immersed from the first in the world of the others: we see their loneliness and their disconnect, but also their humanity. All of a sudden, we see how our marginalization hurts these children, how adults have either taken away their hope and happiness or have been unable to provide for their child despite their love. Harry Potter has no recourse against the Dursley family who imprison him in the cupboard under the stairs after he is orphaned as a baby. He assumes he simply must exist as best he can on cast-offs and scraps until he is legally able to leave home. In a similar way, Paddington Bear arrives at Paddington Station in London trusting that someone kind will adopt him to their family (just as his Aunt Lucy trusted by sending him), and not some evil-hearted taxidermist. Paddington is as vulnerable here as any child alone in a grown-up world.

Yet, in their fictional worlds, these children become loved and accepted by virtue of embracing their otherness - we as readers are normalized into their lack of normality. More, they become the type of heroes we want our children to be like - kind, brave, loyal, and hopeful. Indeed, we see Harry remain hopeful when all hope seems lost, and stand up for those who have accepted and loved him. We know Harry Potter grows up to be a highly-skilled worker, and good husband and father. We also know that the Brown family who adopt Paddington love him just as he is and support his ideas for the future: "Mrs Brown says that in London everyone is different, and that means anyone can fit in. I think she must be right - because although I don't look like anyone else, I really do feel at home. I'll never be like other people, but that's alright, because I'm a bear. A bear called Paddington." In these stories, the otherness of the main characters becomes the very thing that is loved.

Indeed, both Harry Potter and Paddington Bear are seeking asylum in their new worlds: Hogwarts and London. While there are always adults who (eventually) realise the value of protecting and loving the Harry Potters and Paddingtons of the world, not all children have this same happy ending. Not all children who arrive seeking asylum are given the same reasons to hope for their futures. In real life, a child's otherness can be heightened, exacerbated, to make them alien to our community norms. In this way, there is arguably a disconnect at times between the perception that children must be protected, the assumption that 'of course' children are protected, and the reality of who is protected and how this protection is enacted.

This disconnect is demonstrated in how governments around the world have at times treated those seeking asylum, particularly children, to their country. People seeking asylum are arguably seeking hope - many have escaped trauma in an attempt to find safety in a new land. Asylum seekers hope that there is a better life elsewhere. Yet, lingering threats of incarceration and indefinite process times from a power potentially never seen by the asylum seekers can arguably destroy any hope of that new and better life. Worse though, is the idea that a child may grow up in such an environment, never knowing that hope is theirs, that there is another way to live. 
The loss of hope can be invisible - hope is not something we see - yet its impact can be devastating. Viktor Frankl argued that his survival in a Nazi concentration camps was based in the consistency of his hope: he never gave up hope that he would eventually be freed. Many of Frankl's fellow prisoners were more ostensibly hopeful in that they set dates along the lines of 'don't worry, we will be out by Christmas'. When this did not happen, hope's timeline would change to 'Easter', then 'summer'. Yet, with each denial, a little bit of hope was eroded, because hope in this case did not have an everlasting reserve, it was a commodity to be used wisely, almost frugally. By not setting himself up for the possibility of direct failure, Frankl was able to keep hold of his prized and ultimately lifesaving commodity of hope. If hope had been taken forcibly from Frankl, his story of survival may have been different; indeed, he may simply have not survived. Consequently, his later work argued that that hope was a commodity to be valued above all others. It can remain, flickering, when all other rights have been lost to an unrestrained power but, once gone, it may never be recovered. A person's ability to see outside a traumatic experience is one often grounded in hope - the ability to see a positive potential in the future. The loss of this vision can be catastrophic to a person's wellbeing.

International events over the past years - as children remain stuck in refugee camps and detention centres around the world, or have lost their lives trying to find a new and safer home - have further demonstrated the deadliness of this disconnect. In September 2015, photos emerged depicting the aftermath of the sinking of a boat carrying asylum seekers from Syria to Turkey. Two photos were particularly circulated. The first of a toddler dressed in a red t-shirt and shorts lying face-down on a beach as waves swept over his lifeless body. The second of a Turkish policeman carrying the limp body of this same three-year-old boy drowned along with almost all his family. While the plight of such asylum seekers - who take extraordinary risks sailing across the sea in Europe searching for a safer life - has long been debated, these photos seemed to strike a chord as they were published throughout the world. This three-year-old did not epitomise all the evils that asylum seekers had been previously painted with - there was no threat to social norms in a toddler, let alone one who is deceased. And in this tragedy, the narrative's language changed. These images could have been simply one of an 'asylum seeker', without name or nationality, where the deceased remained othered and unidentified. However, this picture caused such outcry that the child was named - Aylan Kurdi - and the story of his family detailed. In this way, in their death, their humanity was recognized, whereas in the 'asylum seeker' state, their humanity was far more problematized. In death, they were given the potential for a future in which they value-added to a community, as opposed to only being a destructive force. Consequently, Aylan Kurdi's hope was returned to him post mortem: his life was one of potential cut short. Of course, hope without life is pointless to the deceased. And in this way, these images brought the debates around asylum seekers to a base foundation: what right does a child have to life? Where the debates in countries valorized by asylum seekers focus on the quality of a child's life, the debates in the countries they seek to escape simply revolve around survival and safety. The narrative of asylum seekers is relative: stay and remain at risk of death, leave and grasp the potential for a life where violence and death are no longer normalized. 
The UN Convention on the Rights of the Child 1989 (CRC) specifically recognizes that every child has the "inherent right to life" (Article 6(1)). More than this though, the Convention sets out other Articles which speak to a child being allowed to thrive, more than simply survive - they aim to protect and enhance the quality of the child's life. While hope is not explicitly mentioned, dignity is mentioned eight times throughout the document - humanity and dignity here are inextricably linked. However, hope is implied in Article 39, which focuses on the recovery of a child after neglect, abuse, or torture and "shall take place in an environment which fosters the health, self-respect and dignity of the child". Places like this may readily exist in literature - the acceptance of Hogwarts helped to heal an abused Harry Potter - but how do we ensure all children live in such an environment? Indeed, the rights set forth in the CRC are all the more important given the lack of legal and social status children hold until they are recognised to be an adult. As any person with knowledge of mental health will tell you, it is not possible to return the child's hope to them when they become an adult. The loss of hope is deep and may be irreversible.

Towards the end of the first Harry Potter novel, Dumbledore talks to Harry about the Mirror of Erised:

Let me explain. The happiest man on earth would be able to use the Mirror of Erised like a normal mirror, that is, he would look into it and see himself exactly as he is.... It shows us nothing more or less than the deepest, most desperate desire of our hearts. You, who have never known your family, see them standing around you...

Harry had been sneaking away to the mirror to see his family, not realizing he was becoming mired in the past, rather than looking forward to the future. Memories of his past trauma and abuse froze him in a state of hopelessness - what he wished for in the mirror could never exist. With Dumbledore's support, Harry is able to forge a new path to a new future he had never imagined until that first letter arrived to this cupboard. Similarly, Paddington Bear - who may well have seen only his reflection in the Mirror, perhaps with a stack of marmalade sandwiches - was able to start a new life thriving in the diversity and comfort of London. These hopeful futures should not just be limited to fiction.

For more on Harry Potter, see Rowling, J.K. Harry Potter and the Philosopher's Stone.

For more on Paddington, see

For more on understanding hope through adversity, see Viktor E. Frankl, (1946). Man's Search for Meaning.

For more on the Syrian-Turkey drowning tragedy see http://www.theguardian.com/world/2015/sep/02/shocking-image-of-drowned-syrianboy-shows-tragic-plight-of-refugees. 
For more on children's human rights, see the UN Convention on the Rights of the Child: http://www.ohchr.org/en/professionalinterest/pages/crc.aspx 